\title{
Pengolahan Kotoran Ternak Menjadi Pupuk Organik Dalam Upaya Meningkatkan Pendapatan Peternak Pada Kelompok Tani-Ternak "Beriuk Taker” Di Desa Dasan Cermen Kecamatan Sandubaya Kota Mataram
}

\author{
Soekardono*, M. Yasin, Anwar Fachry, Moh. Taqiuddin, Maya Nachida \\ Fakultas Peternakan, Universitas Mataram, Mataram, Indonesia
}

\author{
Article history \\ Received: 30-11-2020 \\ Revised: 09-03-2021 \\ Accepted: 08-03-2021 \\ *Corresponding Author: \\ Soekardono, \\ Fakultas Peternakan, \\ Universitas Mataram, Mataram, \\ Indonesia;
}

Email:

kardonowiyono@yahoo.com
Abstract: City of Mataram City is the center of government and economic activity. Urban-Village of DasanCermen, district of Sandubaya, has been selected as site of community service with consideration that there are several livestock-farmers group, namely: the cattle-farmers group, the Buras Chicken-Farmer Group, the Duck-Farmers Group, and the Fish- Farmers Group. The existence of these livestock-farmer groupshave been used as an educational tourism-site by the Urban-Village Government. The cattle-farmer group of "Beriuk Taker" is located close to the urban-village office and residential areas so that accumulated-manure disturbs environmental health. Therefore, the aim of this community service is to find solution problem of accumulated-livestock manure by processing it into organic fertilizer. In addition, this service also provides knowledge and skills about group-based business management to group committee.The methods have been used in this activity are extension service on implementation of cattle-business technology, training on processing organic fertilizers, and focus group discussions (FGD) on cattle-group management. The service results showed: (1) positively response of beneficiary group to the community service; (2) cattle-farmers capable and willing to apply technology about feed, cattleshed, and marketing;(3) cattlefarmers are skilled in processing of organic fertilizer by mutually work in every Sunday after zuhr prayer. The processing of organic fertilizer can produce $1-1.5$ tons in 3 weeks. The temporary marketing is directed to ornamental-plant entrepreneurs around in the city of Mataram. It is hoped that the proceeds from the sale of fertilizers can be used to pay land rent to the local mosque management. With the support of the village government, the "Beriuk Taker" cattle farmer group can be used as a location for livestock education. They planned that the income from sale of organic fertilizerwould be used to pay land-rent to the local mosque committee.With the support of the urban-village government, the cattle-farmers group of "Beriuk Taker" can be used as site for livestock'educational-tourism.

Keywords: cattle-farmer group; cattle; organic fertilizer; income; educational-tourism

Abtrak: Kota Mataram merupakan pusat pemerintahan kota dan pusat aktivitas perekonomian. Kelurahan Dasan Cermen Kecamatan Sandubaya dipilih sebagai lokasi pengabdian kepada masyarakat karena di seputaran Kantor Desa terdapat beberapa kelompok tani-ternak, yaitu Kelompok Tani-Ternak Sapi, Kelompok Tani-Ternak Ayam Buras, Kelompok Tani-Ternak Itik, dan Kelompok Tani-Ternak Ikan. Kelompok tani-ternak tersebut oleh kelurahan dimanfaatkan sebagai lokasi edu-wisata. Kelompok tani-ternak Sapi "Beriuk Taker" terletak dekat kantor desa dan perumahan penduduk sehingga kotoran ternak yang menumpuk mengganggu 
kesehatan lingkungan. Oleh karena itu, tujuan pegabdian kepada masyarakat ini adalah untuk mengatasi penumpukan kotoran ternak dengan cara mengolahnya menjadi pupuk organik. Selain itu tujuan pengabdian ini adalah memberikan pengetahuan dan ketrampilan manajemen usaha berbasis kelompok kepada para pengurus kelomok. Metode yang digunakan dalam pengabdian ini adalah penyuluhan tentang penerapan teknologi usaha ternak, pelatihan pembuatan pupuk organik, dan focus group discussion (FGD) tentang manajemen kelompok. Hasil pengabdian menunjukkan: (1) respon positif terhadap kegiatan pengabdian yang dilakukan, (2) peternak merasa mampu dan mau menerapkan teknologi terutama terkait pakan, perkandangan, dan pemasaran, (3) peternak telah terampil membuat pupuk organik yang dilakukan secara gotong-royong setiap hari Minggu setelah sholat dhuhur. Kegiatan pembuatan pupuk organik dapat menghasilkan 1-1,5 ton per 3 minggu. Pemasaran pupuk organik sementara diarahkan kepada para pengusaha tanaman hias yang banyak tersebar di wilayah Kota Mataram. Diharapkan hasil penjualan pupuk dapat digunakan untuk membayar sewa lahan kepada pengurus Masjid setempat. Dengan dukungan pemerintah kelurahan kelompok tani-ternak sapi "Beriuk Taker" dapat dijadikan lokasi edu-wisata ternak.

Kata Kunci: kelompok; ternak-sapi; pupuk-organik; pendapatan; edu-wisata

\section{PENDAHULUAN}

Kota Mataram merupakan salah satu dari 10 kabupaten/kota di Provinsi NTB. Kota Mataram menjadi kota yang strategis karena selain sebagai pusat pemerintah kota juga pusat pemerintah Provinsi. Oleh karena itu Kota Mataram menjadi pusat konsumen berbagai produk termasuk produk peternakan. Selain itu Kota Mataram juga sebagai daerah destinasi wisata. Wisatawan baik dari manca negara maupun domestik, umumnya selalu mengunjungi pusat-pusat wisata di Kota Mataram, walaupun tujuan utama mereka di luar Kota seperti Senggigi, Mandalika, Sekotong, Sembalun, dan sebagainya. Kota Mataram memiliki enam kecamatan, yaitu Kecamatan Mataram, Kecamatan Cakranegara, Kecamatan Selaparang, Kecamatan Ampenan, Kecamatan Sekarbela, dan Kecamatan Sandubaya.

Kecamatan Sandubaya, di mana kegiatan pengabdian kepada masyarakat dilakukan, terdiri atas tujuh kelurahan, yaitu: Dasan Cermen, Abian Tubuh Baru, Babakan, Turida, Mandalika, Bertais, dan Selagalas. Lokasi pengabdian kepada masyarakat ini akan dipusatkan di Kelurahan Dasan Cermen. Di Kelurahan Dasan Cermen ini terdapat wilayah di seputaran Kantor Desa yang cukup menarik dan unik dalam bidang peternakan. Ada Kelompok Tani-Ternak Sapi, Kelompok TaniTernak Ayam Buras, Kelompok Tani-Ternak Itik, dan Kelompok Tani-Ternak Ikan terintegrasi dengan unggas (Itik dan ayam). Menariknya adalah, kelompok tani-ternak ini di create oleh Karang Taruna setempat menjadi lokasi edu-wisata. Untuk menuju lokasi kelompok-kelompok tersebut telah dibuatkan papan arah jalan.

Dasan cermen terletak sekitar $7 \mathrm{~km}$ dari pusat Kota Mataram, memiliki luas wilayah 1,58 km², jumlah penduduk sekitar 5.026 jiwa, kepadatan penduduk 3.181 jiwa $/ \mathrm{km}^{2}$, dan 1.536 Rumah Tangga. Pekerjaan penduduk meliputi pertanian, peternakan, konstruksi, transportasi, keuangan, jasa, industri rumah tangga/kerajinan, dan lain-lainnya. Walaupun yang berusaha dalam bidang peternakan relatif sedikit tetapi memiliki peran cukup penting. Misalnya, peternak itik sangat besar kontribusinya di dalam memasok telur untuk industri telur asin. Produk telur asin merupakan salah satu produk yang mendukung pariwisata. Ternak sapi walaupun jumlahnya relatif kecil tetapi mempunyai sumbangan 
yang relatif besar bagi pendapatan rumah tangga peternak. Selain itu kelompok tani-ternak sapi dapat menjadi pusat pembelajaran bagi para pelajar dan masyarakat pada umumnya sehingga dikenal sebagai "edu-wisata ternak sapi".

Kelompok tani-ternak "Beriuk Taker" memiliki anggota 24 orang dengan jumlah sapi sekitar 50 ekor atau rata-rata pemilikan ternak 2 ekor. Ternak sapi lebih banyak dikandangkan. Penyediaan pakan dilakukan secara cut and carry (menyediakan pakan dengan mencari pakan hijauan setiap hari). Penyediaan pakan tersebut selama ini belum menjadi masalah. Masalah utama yang dirasakan adalah mengenai kotoran ternak yang semakin menumpuk sehingga selain mengalami kesulitan tempat pembuangan juga dapat mengganggu kesehatan. Dengan asumsi produksi kotoran ternak $10 \mathrm{~kg} / \mathrm{ekor} /$ hari maka dengan 50 ekor sapi akan menghasilkan kotoran ternak sebanyak $500 \mathrm{~kg}$ per hari, ini belum termasuk kotoran bekas pakan. Luas areal kelompok tani-ternak sapi ini terbatas, hanya sekitar 20 are dan tidak mungkin diperluas lagi. Oleh karena itu, dalam rangka meningkatkan pendapatan peternak dan sekaligus menciptakan lingkungan perkandangan yang bersih dan nyaman untuk mendukung eduwisata ternak sapi, maka perlu dilakukan kegiatan penyuluhan/pelatihan tentang manajemen kelompok tani-ternak dengan focus pengolahan kotoran ternak menjadi pupuk organik.

\section{METODE}

Kegiatan utama dalam pengabdian kepada masyarakat ini adalah penyuluhan dan pelatihan kepada pengurus dan anggota kelompok tani-ternak sapi "Beriuk Taker". Oleh karena itu metode pokok yang digunakan dalam kegiatan pengabdian kepada masyarakat ini adalah metode penyuluhan. Metode ini bertujuan untuk meningkatkan pengetahuan, ketrampilan, dan sikap/tindakan para peternak sehingga mereka mau dan mampu menerapkan teknologi dalam usaha ternaknya sehingga pendapatan usahanya meningkat. Selama ini para peternak masih menganggap bahwa usaha ternak sapi hanya sebagai usaha sambilan. Oleh karena itu, umumnya jumlah sapi yang dipelihara hanya 2 - 3 ekor sesuai dengan kemampuan tenaga kerja keluarga untuk menyediakan pakan sehari-hari.

Para peternak belum memanfaatkan teknologi pakan, seperti teknologi penyimpanan bahan pakan untuk jangka waktu tertentu. Para peternak masih melakukan penyediaan pakan dengan system cut and carry. Penanganan kotoran ternak belum optimal, masih terjadi penumpukan yang menyebabkan pencemaran lingkungan.

Dalam upaya menangani masalah-masalah tersebut, dalam pengabdian kepada masyarakat ini dilakukan kegiatan-kegiatan:

1. Penyuluhan teknik produksi ternak kepada para peternak dengan menggunakan metode ceramah dan diskusi. Materi penyuluhan terdiri atas penerapan panca usaha ternak sapi, analisis ekonomi usaha, dan pemasaran.

2. Pelatihan manajemen kelompok dan usaha kepada pengurus kelompok dengan menggunakan metode diskusi dan praktek. Materi pelatihan terdiri atas funsi-fungsi manajemen usaha ternak sapi, perencanaan bisnis, pembukuan dinamika populasi ternak, dan administrasi keuangan.

3. Pelatihan pembuatan pupuk organic/kompos menggunakan metode praktek langsung. Pembuatan kompos diawali dengan pengumpulan kotoran sapi dengan cara pemanenan dari kandang, dilanjutkan dengan proses pengolahan menjadi kompos (Prihandini and Purwanto, 2007 dalam Ratriyanto, dkk., 2019). Langkah-langkah pembuatan kompos adalah sebagai berikut:

a. Menyiapkan kotak kompos dari kayu berukuran $(2 \times 1,5 \times 1,5) \mathrm{m}$.

Menyiapkan alat: Keseran (celeng), cangkul, bendo, arit, senggrong, dan sekop. 
b. Menyiapkan bahan baku: limbah kotoran ternak.

c. Menyiapkan bahan tambahan: jerami (dipotong-potong pendek), ranting-ranting, dan cacahan kayu.

d. Penyusunan bahan untuk membuat kompos dengan urutan sebagai berikut:

1) ranting-ranting $10 \mathrm{~cm}, 2$ ) jerami $10 \mathrm{~cm}, 3$ ) kotoran ternak $30 \mathrm{~cm}, 4$ ) disiram larutan EM4, 5) jerami $10 \mathrm{~cm}, 6)$ kotoran ternak $30 \mathrm{~cm}, 7$ ) disiram larutan EM4, 8) demikian seterusnya sampai ketinggian mencapai 1,5 $\mathrm{m}, 9$ ) setelah tinggi mencapai 1,5 m ditutup dengan cacahan kayu setebal $10 \mathrm{~cm}$. Setelah tersusun 1-4 disebut satu lapis, kemudian diulangi lagi susunannya mulai dari 2-4 lagi demikian seterusnya sampai tersusun tiga lapis dan paling atas diberi cacahan kayu setebal $10 \mathrm{~cm}$ lalu disiram air. Cacahan kayu kayu berfungsi untuk mengurangi bau yang keluar dan sekaligus untuk menahan air yang masuk ke tumpukan kompos dan menjaga kelembaban.

e. Ditunggu 3 minggu dan dibiarkan saja, kalau kelihatan kering disiram air sedikit dan setelah 3 minggu dibalik, yaitu membalik tumpukan kompos yang dibawah menjadi diatas, sehingga tecampur sempurna.

f. Hasil pembalikan pertama (setelah 3 minggu) kompos sudah hancur dan berwarna hitam, bergumpal kecil-kecil.

g. Menunggu pembalikan kedua 3 minggu kemudian, selanjutnya kompos sudah kelihatan menyerupai tanah, kotoran sudah hancur dan tidak berbau.

h. Selanjutnya menunggu pembalikan ketiga 3 minggu kemudian, di sini kompos sudah jadi

i. Selanjutnya dilakukan penyaringan, dan didiamkan selama 2 minggu

j. Dilakukan pengemasan kedalam sak plastik dan kompos siap digunakan.

\section{HASIL DAN PEMBAHASAN}

\section{Macam Kegiatan}

Kegiatan pengabdian kepada masyarakat ini dilakukan pada kelompok tani-ternak sapi "Beriuk Taker" di Desa Dasan Cermen, Kecamatan Sandubaya, Kota Mataram. Dalam pengabdian masyarakat ini, sengaja dipilih kelompok tani-ternak sapi di pinggiran kota karena usaha ternak ini diduga akan menghadapi masalah penyediakan pakan dan menyebabkan pencemaran lingkungan. Dalam kelompok tani-ternak ini memiliki 24 peternak anggota dengan rata-rata pemilikan ternak sapi 1-2 ekor. Jumlah ternak sapi saat pengabdian dilaksanakan sebanyak 35 ekor. Dari 24 orang anggota hanya 6 (enam) peternak yang memelihara sapi induk selain juga jantan dan 18 peternak lainnya memelihara sapi jantan untuk sapi potong (penggemukan).

Kegiatan inti dalam pengabdian masyarakat ini adalah (1) memberikan penyuluhan tentang teknik produksi terutama teknik produksi penggemukan, (2) memberikan penyuluhan tentang manajemen usaha terutama pemasaran baik tentang pembelian sapi bakalan maupun penjualan sapi potong, dan (3) pelatihan dan praktek pembuatan pupuk organik. Untuk pembuatan pupuk organic, karena kelompok telah melaksanakan pembuatan pupuk organic secara manual maka dalam pelatihan ini lebih diarahkan untuk peningkatan kualitas, packing, dan pemasaran.

Kegiatan pengabdian dilaksanakan dalam empat kali pertemuan, setiap kali pertemuan sekitar 3 (tiga) jam efektif. Pada pertemuan pertama, diberikan motivasi kepada para peternak agar lebih semangat berusaha ternak sapi dilanjutkan dengan penyuluhan teknik produksi. Minggu ke-2, diskusi 
dengan pengurus sekaligus memberikan teknik manajemen kelompok dan manajemen usaha. Minggu ke-3 dan ke-4, pelatihan dan praktek pembuatan pupuk organic.

\section{Pencapaian Tujuan}

Tujuan pokok pengabdian kepada masyarakat ini adalah meningkatkan produktivitas usaha ternak sapi berbasis kelompok untuk meningkatkan pendapatan usaha ternak sehingga dapat menambah pendapatan rumah tangga peternak. Untuk mencapai tujuan pokok tersebut terdapat tiga kegiatan seperti yang telah diuraikan di atas.

Pelaksanaan kegiatan berlangsung dengan baik sesuai rencana. Para pengurus dan peternak merespon dengan baik. Mereka disiplin terhadap waktu yang telah disepakati untuk pelaksanaan kegiatan, baik pada saat penyuluhan maupun pelatihan/praktek pembuatan pupuk organik. Selama penyuluhan, para peternak aktif dalam diskusi, mulai dari penyampaian masalah-masalah sampai kepada rencana penyelesaian masalah. Masalah-masalah yang dialami para peternak adalah penyediaan pakan, perkandangan, dan pengelolaan kotoran ternak. Beberapa peternak mengalami masalah permodalan, sehingga mereka terpaksa mengadas miliki tetangga atau milik kelompok. Bagi pengadas milik kelompok, peternak memperoleh 50\% dari keuntungan. Dengan perkiraan pendapatan bersih usaha ternak sapi sekitar Rp. 4 juta,-per ekor per tahun, maka peternak pengadas milik kelompok dapat memperoleh pendapatan sekitar Rp. 2 juta per ekor per tahun. Bagi peternak dengan modal sendiri, mempunyai kewajiban iuran untuk kelompok sebanyak $20 \%$ dari keuntungan setiap penjualan ternaknya. Uang yang terkumpul pada kelompok digunakan yang utama adalah untuk membayar sewa lahan sebanyak Rp. 10 juta,- per tahun ke pengelola Masjid setempat. Kelompok menerima uang selain dari iuran peternak juga dari hasil penjualan pupuk.

\section{Pencapaian Sasaran}

Ditinjau dari sisi peserta, sasaran pengabdian kepada masyarakat ini adalah petani-peternak dan pengurus kelompok tani-terak Beriuk Taker. Sasaran kegiatan terdiri atas seluruh peternak anggota kelompok sebanyak 24 orang dan pengurus kelompok sebanyak 7 orang. Mereka semuanya aktif mengikuti acara kegiatan pengabdian kepada masyarakat ini. Dilihat dari jumlah dan keaktifan peserta selama kegiatan, maka dapat dikatakan bahwa sasaran pengabdian ini ditinjau dari sisi peserta tergolong berhasil.

Dari sisi output, sasaran pengabdian kepada masyarakat ini adalah para peternak memiliki ketrampilan teknis dan ekonomis dalam berusaha ternak. Secara teknis, para peternak diharapkan trampil dalam melaksanakan panca usaha ternak sapi, yaitu pemilihan bibit, pemberian pakan, pemeliharaan sehari-hari, penanganan reproduksi ternak (perkawinan ternak), dan penanganan kesehatan ternak. Secara ekonomis, diharapkan para peternak memiliki kemampuan manajerial dalam berbisnis seperti mengalokasikan sumber daya secara efisien, menentukan jumlah pemeliharaan sapi yang optimal, menentukan kapan harus menjual ternak, menentukan harga jual, dan sebagainya. Dalam teknik berternak, umumnya para peternak sudah cukup trampil. Pakan ternak yang diberikan sehari-hari berupa hijauan segar berupa rumput lapangan dan jerami tanaman (kacang tanah, padi, dan jagung). Pakan tersebut disediakan secara cut and carry. Selama ini pakan tidak menjadi masalah karena jumlah pemeliharaan ternak hanya terbatas 1-2 ekor. Pakan konsentrat sangat jarang diberikan karena harga tidak terjangkau. Sebenarnya para peternak sudah memahami bahwa pakan konsentrat sangat penting untuk pertumbuhan sapi penggemukan. Untuk mengatasi penyediaan pakan, para peternak sepakat ke depan perlu ada upaya penyimpanan pakan ternak (stok pakan) untuk minimal 
satu minggu. Sasaran lain yang penting adalah tercapainya memproduksi pupuk organik secara berkelanjutan. Selama ini telah berhasil diproduksi pupuk organik sebanyak 1-1,5 ton per 3 minggu atau sekitar 16 -24 ton per tahun. Dengan harga pupuk Rp. 700,- per kg maka dalam satu tahun dapat diperoleh penghasilan dari penjualan pupuk sebesar Rp. 11.200.000,- sampai Rp. 16.800.000,-.

\section{Pencapaian Manfaat}

Manfaat utama pengabdian kepada masyarakat ini bagi para peternak adalah mereka dapat memiliki pengetahuan, ketrampilan, dan jiwa kewirausahaan sehingga memiliki potensi untuk mengembangkan usahanya lebih besar dan lebih menguntungkan. Tentu saja harus disertai dengan bantuan permodalan dan akses teknologi dan pemasaran. Manfaat bagi pengurus, mereka telah memiliki pengetahuan dan ketrampilan manajemen kelompok dan usaha sehingga menjadi bekal untuk mengembangkan kelompok menjadi kelomok yang mandiri dan maju.

Setelah mengikuti kegiatan pengabdian ini, para pengurus dan peternak mulai menyadari pentingnya teknologi baik teknologi teknis maupun sosial-ekonomi untuk pengembangan usaha ternak sapinya. Mereka menyadari pentingnya memilih bibit, penyimpanan pakan, kebersihan kandang, dan manajemen pemasaran untuk memperoleh pendapatan usaha yang maksimal. Pengurus kelompok juga telah merencanakan untuk mengembangkan pembuatan pupuk organic dengan mencari bantuan untuk mendapatkan mesin pencacah dan mesin pengayak kotoran ternak agar hasil pupuk kandang dapat lebih banyak dan lebih berkualitas.

Manfaat bagi Perguruan Tinggi, program pengabdian kepada masyarakat ini dapat menjadi jembatan penghubung antara Perguruan Tinggi sebagai sumber teknologi dengan para peternak sebagai pelaku utama usaha ternak yang membutuhkan teknologi. Melalui pengabdian kepada masyarakat, Perguruan Tinggi dapat mendesiminasikan hasil-hasil penelitian para dosen dan mahasiswa kepada para peternak sekaligus dapat memperoleh umpan balik mengenai masalahmasalah yang dialami para peternak. Disamping itu, lokasi pengabdian kepada masyarakat dapat dikembangkan menjadi tempat praktek atau PKL mahasiswa.

Manfaat bagi pemerintah, terutama pemerintah kelurahan Dasan Cermen, pengembangan kelompok tani-ternak Beriuk Taker dapat menjadi lokasi edu-wisata ternak yang menarik. Disamping itu, dapat dijadikan percontohan dalam rangka pengembangan usaha ternak sapi yang lebih produktif dan menguntungkan. Usaha ternak sapi yang produktif selain akan memberikan pendapatan yang layak bagi peternak, juga akan mendukung tercapainya program NTB-BSS dan sekaligus mendukung program swasembada daging sapi nasional (PSDS).

Faktor Penghambat dan Pendukung

Beberapa faktor penghambat dalam pengembangan usaha ternak sapi, khususnya pada kelompok tani-ternak "BERIUK TAKER" adalah:

1) Para peternak terbiasa memberikan pakan sapi secara cut and carry. Mencari pakan secara cut and carry tentu hanya dapat menyediakan jumlah pakan yang terbatas, tergantung pada kondisi ketersediaan pakan di lapangan dan tenaga kerja yang tersedia. Pada musim hujan, pakan hijauan cukup melimpah sehingga setiap rumah tangga tani-ternak tidak mengalami kesulitan mencari pakan. Namun demikian, pada musim kemarau ketersediaan pakan hijauan di lapangan sangat terbatas sehingga memerlukan tenaga dan waktu yang lebih banyak untuk mencari pakan. Kondisi demikian menyebabkan produktivitas tenaga kerja keluarga menurun yang dapat mengakibatkan penurunan pendapatan rumah tangga. 
2) Luas areal perkandangan ternak terbatas, hanya 20 are, dan terletak dekat lingkungan perumahan. Kondisi ini merupakan hambatan untuk pengembangan skala usaha. Kelompok tani-ternak mengalami kesulitan untuk menambah luas perkandangan.

3) Proses produksi pupuk organik masih tradisional, semua tahapan mulai dari pencacahan, pengayakan, pencampuran, dan pengepakan dikerjakan secara manual dengan peralatan seadanya. Oleh karena itu hasilnya kurang optimal dalam kuantitas dan kualitas.

Beberapa faktor pendorong dan peluang untuk pengembangan kelompok tani-ternak Beriuk Taker adalah:

1. Para peternak punya motivasi kuat untuk mengembangkan usaha ternak sapi melalui kelompok tani-ternak. Usaha ternak sapi hanya sebagai usaha sampingan. Para peternak memiliki pekerjaan pokok seperti buruh pasar, buruh pabrik, petani, dan pedagang. Namun, kontribusi usaha ternak sapi kepada pendapatan rumah tangga cukup signifikan. Rata-rata para peternak dapat memperoleh pendapatan bersih per periode penggemukan sekitar 5-6 bulan sekitar Rp 4 juta per ekor.

2. Permintaan ternak sapi potong di Kota Mataram relative besar sehingga peternak tidak mengalami masalah dalam pemasaran.

3. Institusi pendukung seperti Dinas Peternakan dan Kesehatan Hewan Provinsi dan Dinas Peternakan Kota Mataram, PT Astra (CSR), BI Mataram (CSR) telah memberikan dukungan berupa perbaikan perkandangan, penyuluhan, dan bantuan peralatan.

\section{KESIMPULAN DAN SARAN}

\section{Kesimpulan}

Hasil pengabdian kepada masyarakat ini dapat disimpulkan sebagai berikut:

1. Perkandangan pada kelompok tani-ternak sapi "Beriuk Taker" dapat diperluas jika masalah penumpukan kotoran ternak dapat diatasi dengan optimalisasi pembuatan pupuk organic sehingga tidak terjadi pencemaran lingkungan. Sisa lahan sekitar 10 are dapat dimanfaatkan untuk membangun kandang baru.

2. Pembuatan pupuk organic dapat dioptimalkan dengan menggunakan mesin pencacah dan penyaring bahan baku (kotoran ternak) sehingga dapat meningkatkan produksi minimal dua kali lipat dari produksi saat ini.

3. Kelompok dapat meningkatkan produktivitas ternaknya dengan menerapkan teknologi pakan, misalnya dengan melakukan penyimpanan pakan yang berkualitas untuk memenuhi kebutuhan minimal satu minggu.

4. Usaha ternak sapi dalam kelompok Beriuk Taker ini merupakan usaha sampingan, namun memiliki kontribusi yang signifikan terhadap pendapatan rumah tangga peternak.

5. Peternak memiliki semangat tinggi dalam mengusahakan ternak sapi, tetapi belum menerapkan teknologi untuk meningkatkan produktivitas ternaknya. Pemeliharaan ternak sehari-hari masih tradisional. 


\section{Saran}

Atas dasar kesimpulan di atas, direkomendasikan hal-hal berikut:

1. Pemerintah melalui Dinas Peternakan dan Kesehatan Hewan Provinsi NTB atau Dinas yang menangani peternakan di Kota Mataram atau instansi lainnya yang terkait perlu memberi bantuan mesin pencacah dan mesin penyaring (ayak) bahan baku dalam proses pembuatan pupuk organik.

2. Kualitas pupuk harus ditingkatkan dengan packing yang bagus dilengkapi label kandungan unsurunsur haranya.

3. Kelompok perlu didorong untuk mengembangkan usaha selain budi daya ternak dan pembuatan pupuk organic, misalnya penjualan daging sapi, telur, pakan ternak, penyediaan kebutuhan rumah tangga sekitar, dan sebaginya.

4. Penyuluhan/pelatihan tentang teknologi peternakan perlu terus dilakukan agar para peternak trampil dan bersedia menerapkan teknologi.

\section{DAFTAR PUSTAKA}

BPS Kota Mataram. 2018. Kota Mataram Dalam angka.

BPS Kota Mataram.2018. Kecamatan Sandubaya Dalam Angka.

Diwyanto,K. 2001. Model Perencanaan Terpadu: Integrasi Tanaman-ternak (Crop-Livestock System). Makalah Seminar Nasional Teknologi Peternakan dan Veteriner, Auditorium Balai Penelitian Veteriner Bogor, 17-18 September 2001.

Fattah, S. 2012. Produktivitas Ternak Sapi Bali. The Phinisi Press. Yogyakarta.

Soekardono. 2009. Ekonomi Agribisnis Peternakan: Teori dan Alikasinya. Penerbit Alademika Presssindo, Jakarta.

Soekardono dan A. Fachry. 2017. Corn And Cattle Integration to Sport NTB's One Million Cattle Programe In Lombok Island. Proceedings The $7^{\text {th }}$ International Seminar On Tropiccal Animal Production, September 12-14, 2017, Yogyakarta, Indonesia. ISBN: 978-979-111529-9

Ratriyanto, A., S.D. Widyawati, W.P.S. Suprayogi, S. Prastowo, dan N. Widyas. 2019. Pembuatan Pupuk Organik dari Kotoran Ternak Untuk Meningkatkan Produksi pangan. Jurnal SEMAR Vol. 8 No. 1, 2019 hal. 9 - 13 ISSN: 2302-3937 | Copyright (C LPPM Universitas Sebelas Maret Homepage: https://jurnal.uns.ac.id/jurnal-semar. 